medRxiv preprint doi: https://doi.org/10.1101/2021.03.19.21253920; this version posted March 22, 2021. The copyright holder for this preprint (which was not certified by peer review) is the author/funder, who has granted medRxiv a license to display the preprint in perpetuity.

It is made available under a CC-BY-NC-ND 4.0 International license .

\title{
Reduced BNT162b2 mRNA vaccine response in SARS-CoV-2-naive nursing home residents
}

David H. Canaday ${ }^{1,2}$, Lenore Carias ${ }^{1}$, Oladayo A. Oyebanji ${ }^{1}$, Debbie Keresztesy ${ }^{1}$, Dennis Wilk ${ }^{1}$, Michael Payne ${ }^{1}$, Htin Aung ${ }^{1}$, Kerri St. Denis ${ }^{3}$, Evan C. Lam ${ }^{3}$, Brigid Wilson ${ }^{2}$, Christopher F. Rowley ${ }^{4}$, Sarah D. Berry ${ }^{5}$, Cheryl M. Cameron ${ }^{1}$, Mark J. Cameron ${ }^{1}$, Alejandro B. Balazs ${ }^{3}$, Stefan Gravenstein $^{5 *}$, Christopher L. King ${ }^{1 *}$

${ }^{1}$ Case Western Reserve University School of Medicine, Cleveland, $\mathrm{OH}$

${ }^{2}$ Geriatric Research, Education and Clinical Center, Cleveland VA

${ }^{3}$ Ragon Institute of MGH, MIT and Harvard, Cambridge, MA

${ }^{4}$ Division of Infectious Diseases, Beth Israel Deaconess Medical Center, Boston, MA

${ }^{5}$ Marcus Institute for Aging Research, Hebrew SeniorLife, Boston, MA.

${ }^{6}$ Alpert Medical School of Brown University, Providence, RI

${ }^{*}$ Contributed equally to the work

Corresponding author: David.Canaday@case.edu

\section{Abstract}

The SARS-CoV-2 pandemic impact on nursing home $(\mathrm{NH})$ residents prompted their prioritization for early vaccination. To fill the data gap for vaccine immunogenicity in $\mathrm{NH}$ residents, we examined antibody levels after BNT162b2 mRNA vaccine to spike, receptor binding domain (RBD) and for virus neutralization in $149 \mathrm{NH}$ residents and 111 health care worker controls. SARSCoV-2-naive $\mathrm{NH}$ residents mount antibody responses with nearly 4-fold lower median neutralization titers and half the anti-spike level compared to SARS-CoV-2-naive healthcare workers. By contrast, SARS-CoV-2-recovered vaccinated $\mathrm{NH}$ residents had neutralization, anti-spike and anti-RBD titers similar to SARS-CoV-2-recovered vaccinated healthcare workers. NH residents' blunted antibody responses have important implications regarding the quality and durability of protection afforded by neoantigen vaccines. We urgently need better longitudinal evidence on vaccine effectiveness specific to $\mathrm{NH}$ resident populations to inform best practices for $\mathrm{NH}$ infection control measures, outbreak prevention and potential indication for a vaccine boost.

\section{Main text}

The SARS-CoV-2 pandemic has severely affected nursing home $(\mathrm{NH})$ residents prompting their prioritization for early vaccination. Recent reports show the BNT162b2 mRNA vaccine reduces COVID-19 hospitalization and mortality ${ }^{1,2} 3,4$. However, no BNT162b2 mRNA vaccine phase 3 trial immunogenicity data exists for $\mathrm{NH}$ residents; their multiple morbidities, medications, and extreme age may blunt their immune response. Here, we examined antibody response to BNT162b2 mRNA vaccine in NH residents.

We obtained study approval from the New England IRB and consented subjects per protocol. We recruited $\mathrm{NH}$ residents for vaccination with and without prior SARS-CoV-2 infection (age 4899, median age $76 ; n=149$ ) and control comparators that included 1 ) healthcare workers (age 2678; median age 48; $n=111$ ) with and without prior SARS-CoV-2 infection and, 2) an unvaccinated convalescent group 29-94 days after SARS-CoV-2 infection (age range 25-61, median age 53; $\mathrm{n}=22$ ) with asymptomatic or mild disease (Table 1). All NH residents and 72 of 111 healthcare worker controls provided baseline blood samples 1-14 days before BNT162b2 mRNA vaccination and all were sampled $14 \pm 3$ days after their second dose. We evaluated IgG to spike protein and 
medRxiv preprint doi: https://doi.org/10.1101/2021.03.19.21253920; this version posted March 22, 2021. The copyright holder for this preprint (which was not certified by peer review) is the author/funder, who has granted medRxiv a license to display the preprint in perpetuity. It is made available under a CC-BY-NC-ND 4.0 International license .

its receptor binding domain (RBD) using bead-multiplex immunoassay and serum neutralization titers in a SARS-CoV-2-pseudovirus neutralization assay ${ }^{5}$.

Figure 1 compares $\mathrm{NH}$ residents' post-vaccination antibody with younger healthcare worker controls, stratified by prior SARS-CoV-2 infection as determined by antibody and/or PCR by the time of vaccination. SARS-CoV-2-naive NH residents mount antibody responses with nearly 4-fold lower median neutralization titers ( 521 vs $135, p<0.0001)$ and half the anti-spike level (4177 vs $1029, p<0.0001$ ) compared to SARS-CoV-2-naive healthcare workers. After vaccination, $17 \%$ of SARS-CoV-2-naive NH residents have neutralizing titers at or below the lower limit of detection with only $1.3 \%$ of SARS-CoV-2-naive healthcare workers that low. Similarly, fewer vaccinated SARS-CoV-2-naive $\mathrm{NH}$ residents compared to vaccinated SARS-CoV-2 naive controls $(36 \%$ vs $85 \%$ ) have neutralization titers above the median of the unvaccinated SARS-CoV-2 convalescent younger adults. By contrast, neutralization, anti-spike and anti-RBD titers in SARS-CoV-2recovered $\mathrm{NH}$ residents receiving vaccine were similar to SARS-CoV-2-recovered vaccinated healthcare workers ( $p>0.24$ in all). $\mathrm{NH}$ residents' blunted antibody responses have important implications regarding the quality and durability of protection afforded by neoantigen vaccines. We urgently need better longitudinal evidence on vaccine effectiveness specific to $\mathrm{NH}$ resident populations to inform best practices for $\mathrm{NH}$ infection control measures, outbreak prevention and potential indication for a vaccine boost.

Support from NIH (Al129709-03S1, 3P01AG027296-11S1, and U01 CA260539-01) and VA

\section{References}

1. Walsh EE, Frenck RW, Jr., Falsey AR, et al. Safety and Immunogenicity of Two RNA-Based Covid-19 Vaccine Candidates. N Engl J Med 2020;383:2439-50.

2. Polack FP, Thomas SJ, Kitchin N, et al. Safety and Efficacy of the BNT162b2 mRNA Covid-19 Vaccine. N Engl J Med 2020;383:2603-15.

3. Chidambaram P, Garfield R, Neuman T, Levitt L. Is the End of the Long-Term Care Crisis Within Sight? New COVID-19 Cases and Deaths in Long-Term Care Facilities Are Dropping. Kaiser Family Foundation 2021.

4. Mor V, Gutman R, Yang A, et al. Short Term Impact of Nursing Home SARS-CoV-2 Vaccinations on New Infections, Hospitalizations and Deaths. J Am Geriatr Soc 2021;in press.

5. Garcia-Beltran WF, Lam EC, Denis KS, et al. Circulating SARS-CoV-2 variants escape neutralization by vaccine-induced humoral immunity. medRxiv 2021. 
medRxiv preprint doi: https://doi.org/10.1101/2021.03.19.21253920; this version posted March 22, 2021. The copyright holder for this preprint (which was not certified by peer review) is the author/funder, who has granted medRxiv a license to display the preprint in perpetuity. It is made available under a CC-BY-NC-ND 4.0 International license.

\section{Table 1 Demographics of Cohorts}

\begin{tabular}{|c|c|c|c|c|c|}
\hline & $\begin{array}{l}\text { Control, } \\
\text { COVID } \\
\text { naïve } \\
(n=76)\end{array}$ & $\begin{array}{l}\text { Control, } \\
\text { prior } \\
\text { COVID } \\
(n=35)\end{array}$ & $\begin{array}{c}\mathrm{NH}, \\
\text { COVID } \\
\text { naïve } \\
(\mathrm{n}=90)\end{array}$ & $\begin{array}{l}\text { NH, prior } \\
\text { COVID } \\
(n=59)\end{array}$ & $\begin{array}{l}\text { Unvaccinated } \\
\text { comparator } \\
(n=22)\end{array}$ \\
\hline Age: mean +/- SD & $49+/-11$ & $48+/-12$ & $78+/-11$ & $78+/-10$ & $46+/-13$ \\
\hline Age: Median (IQR) & $48(39,56)$ & $49(38,56)$ & $76(70,87)$ & $77(71,87)$ & $53(36,56)$ \\
\hline Age: Range & $26-78$ & $30-78$ & $48-99$ & $61-99$ & $25-61$ \\
\hline $\begin{array}{l}\text { Race \& Ethnicity: } \\
\text { White,non-Hispanic }\end{array}$ & 62 (82\%) & $29(83 \%)$ & $79(88 \%)$ & $50(85 \%)$ & 17 (77\%) \\
\hline $\begin{array}{l}\text { Race \& Ethnicity: } \\
\text { African American, } \\
\text { non-Hispanic }\end{array}$ & $5(7 \%)$ & $6(17 \%)$ & $9(10 \%)$ & $9(15 \%)$ & $5(23 \%)$ \\
\hline $\begin{array}{l}\text { Race \& Ethnicity: } \\
\text { Hispanic }\end{array}$ & $4(5 \%)$ & $0(0 \%)$ & $1(1 \%)$ & $0(0 \%)$ & $0(0 \%)$ \\
\hline $\begin{array}{l}\text { Race \& Ethnicity: } \\
\text { Asian }\end{array}$ & $5(7 \%)$ & $0(0 \%)$ & $1(1 \%)$ & $0(0 \%)$ & $0(0 \%)$ \\
\hline Gender: Male & $39(51 \%)$ & $13(37 \%)$ & 57 (63\%) & $35(59 \%)$ & $8(36 \%)$ \\
\hline Gender: Female & $37(49 \%)$ & $22(63 \%)$ & 33 (37\%) & $24(41 \%)$ & $14(64 \%)$ \\
\hline
\end{tabular}




\section{Neutralizing titer}

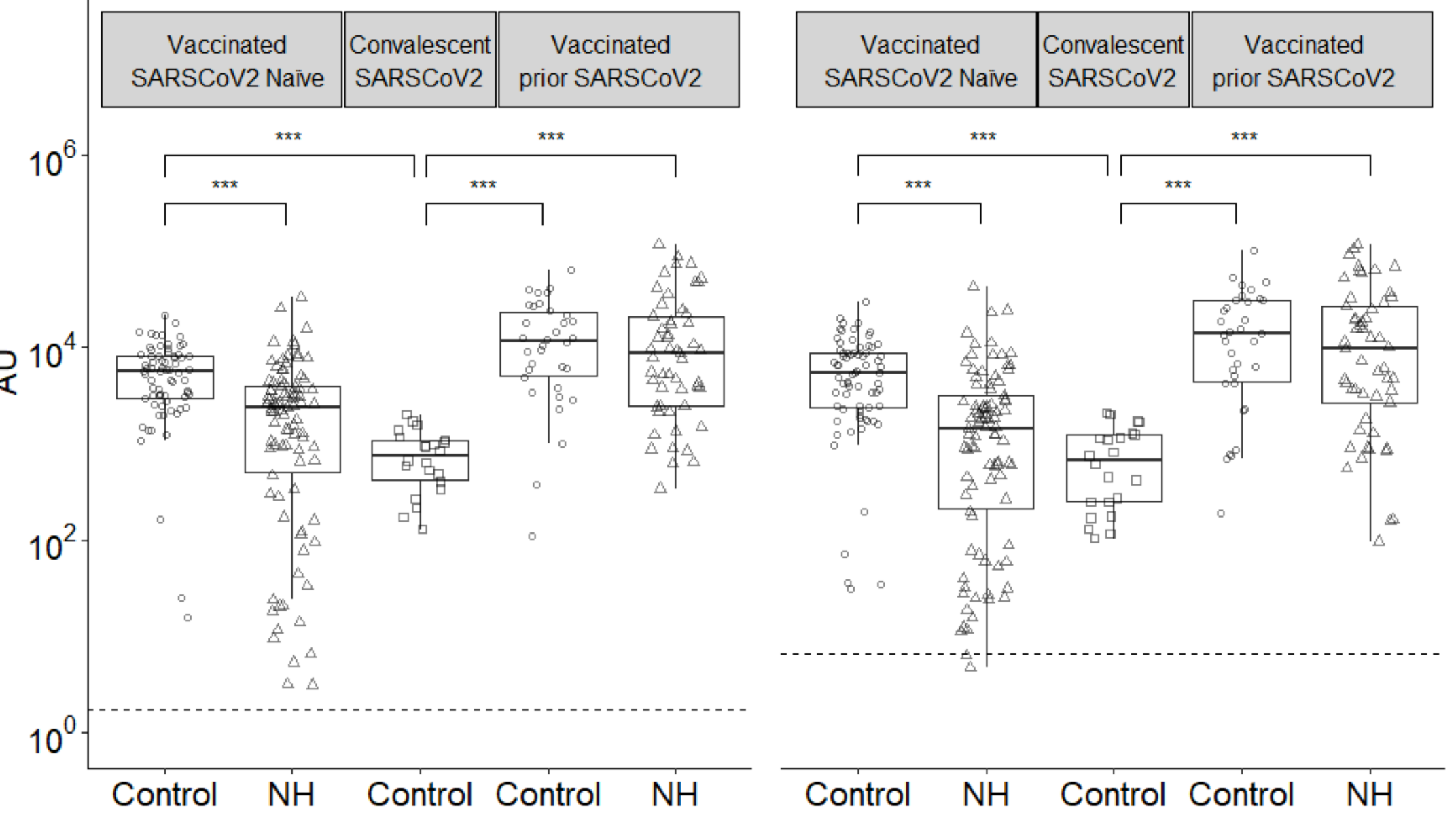

\begin{tabular}{|c|c|c|c|}
\hline $\begin{array}{c}\text { Vaccinated } \\
\text { SARSCoV2 Naive }\end{array}$ & $\begin{array}{l}\text { Convalescent } \\
\text { SARSCoV2 }\end{array}$ & $\begin{array}{c}\text { Vaccinated } \\
\text { prior SARSCoV2 }\end{array}$ \\
\hline
\end{tabular}

$10^{1}$

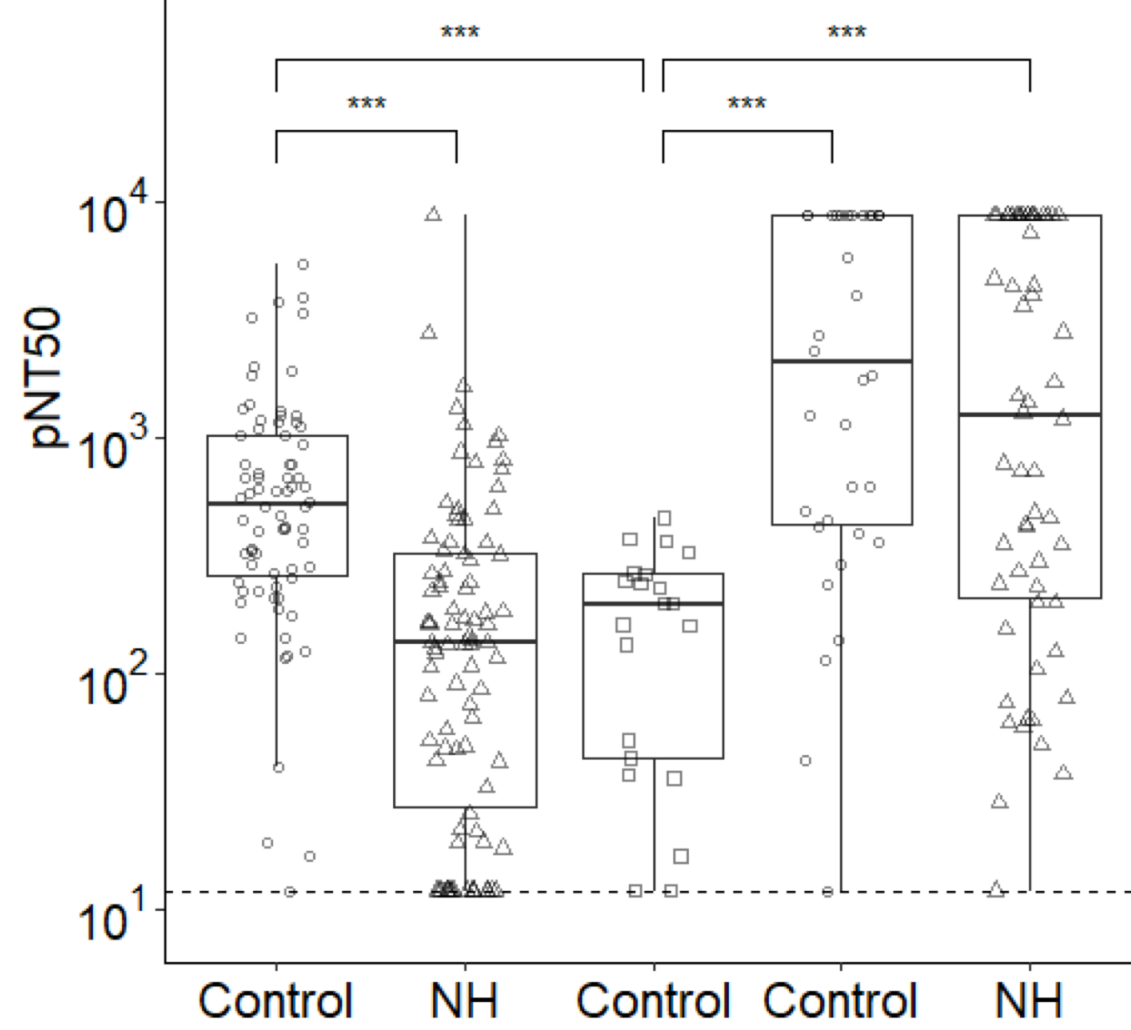

Figure 1. Humoral immune assessment of BNT162b2 mRNA vaccine vaccination in NH residents

Post-vaccination anti-spike, anti-RBD and serum neutralization titers are shown. On the $x$ axis, $\mathrm{NH}$ refers to NH residents and Control refers to the vaccinated younger healthcare workers or unvaccinated SARS-CoV-2 convalescent individuals. The dotted line in each panel is the median pre-immunization value in the SARS-CoV-2-naive subjects. Anti-Spike and Anti-RBD differences in geometric means were assessed using t-tests of log-transformed values. Given observed points at upper and lower limits of detection in neutralizing titer assay (12-8748), differences in distribution were assessed using the Wilcoxon rank-sum test. Pvalues were adjusted within assay ( $n=6$ tests per assay, Bonferroni method), and adjusted $p$-values $<0.001$ are indicated with stars $\left({ }^{* *}\right)$. We did not detect significant differences in any assay between the NH and Control subjects with prior SARS-CoV-2 or between the SARS-CoV-2-naive NH subjects and the convalescent unvaccinated controls. 